\title{
How to win back the disgruntled consumer? The omni-channel way
}

\author{
A. Shivakanth Shetty \\ Jeevananda. $S$ \\ Jayanth R. Kalghatgi \\ Institute of Management \\ Christ University, Bangalore, India
}

\begin{abstract}
Key Words
Brand Loyalty, Brand Disloyalty, Omni- Channel Marketing, Brand Advocacy.
\end{abstract}

\begin{abstract}
In a conventional wisdom, it was believed that in traditional consumer journey, consumer will engage in an extended consideration and evaluation before entering into the loyalty loop. But with the emergence of online and offline advocacy the modern consumers may skip various traditional phases and may directly enter into loyalty loop. Being well informed and empowered modern-day consumer would wait hardly few seconds before he shifts loyalty to the rival brands. Hence, the retailers and marketers need to deal with well informed and empowered consumers who are disloyal to the core. Therefore, this paper proposes the adoption of Omni-channel marketing as a strategy to deal with disloyal customers. This study is both analytical and theoretical in nature and is based on the secondary data as well as extensive review of literature on the subject.

The findings of the study recommend that the adoption of Omni-channel marketing will reduce the loyalty depressing factors and increases the loyalty supporting factors amongst the consumers by creating seamless experience throughout their consumer journey. Therefore, this paper proposes the adoption of Omni channel marketing to retailers, brands and marketers to deal with well informed, empowered and disloyal consumers and to convert them into loyal consumers.
\end{abstract}

Corresponding author: A. Shivakanth Shetty

Email addresses for corresponding author: sivakantha.setty@christuniversity.in

First submission received: $2^{\text {nd }}$ August 2017

Revised submission received: $8^{\text {th }}$ December 2018

Accepted: $15^{\text {th }}$ February 2018

\section{Introduction}

For more than a century, marketers followed the conventional wisdom that, consumer buying decisions followed a linear, top-down progression known as the funnel. This conventional wisdom of marketers has forced them to attract and capture consumer attention at the top of the funnel and guiding them through the entire purchase process. However, thanks to revolution of internet and digitalization, consumer decision journey is no longer linear. The new breed of consumer is not handicapped by the asymmetry of information; rather he has access to all the information needed to take the right and rational decisions. The modern 'empowered' consumer has multitude of options to choose from, high expectations from the brands, very skillful in bargain hunting, disloyal and doesn't think twice in switching over to the competitor's brand.

High costs are involved in consumer loyalty programmes and consumer acquisition for the companies and marketers. Unwittingly, most of the times modern retailers are more occupied themselves in shaping consumer journeys rather than following and understanding their experience and loyalty to a brand. Uunderstanding of consumer's psyche, quest for instant gratification, raising expectations, and engage them at any stage of new consumer journey both in physical and digital world is more important. Hence, the present paper adopts the exploratory and conceptual investigation to ascertain the reasons for brand infidelity amongst empowered consumers and conceptualise and develop (not to create) an Omnichannel model to neutralise the factors triggering the brand disloyalty and trigger the stimuli to augment the brand loyalty amongst the consumers. 


\section{The journey of consumer from loyalty to disloyalty: review of literature}

The topic of brand loyalty has been a very popular amongst both academicians and practioners since 1920s. The first authentic and meaningful discussion on brand loyalty emerged in 1940s, starting from Churchill (1942) who presented the first panel data on brand switching behaviour of customers, followed by Brown (1952) who used the behavioural and attitudinal approaches to measure the brand loyalty. Cunningham (1956) coined the term of 'proportion of purchase', (if a family spends more than 50 percent of its purchases on a particular brand in a particular product category) to examine the behavioural loyalty of the consumers. Pessemier (1959) studied the impact of changes in price contributing for the brand switching behaviour amongst the consumers. Kuehn (1958) and Lipstein (1959) used stochastic modeling to measure the brand loyalty; Frank (1962) introduced measures for return purchase probability as an indicator to measure the brand loyalty. Jacoby and Chestnut (1978) emphasized the usage of attitudinal measures to calculate the brand loyalty and exposed the insufficiency of behavioural measures in measuring the brand loyalty. Aaker (1991) presented the loyalty pyramid to showcase the conversion of customers from indifference to commitment. Dick and Basu (1994) demonstrated the usage of attitudinal measures to show case how and why brand loyalty develops and sustains over a long period of time.

Jones and Sasser (1995) highlighted the paradoxical situation where customers at the lowest level are enthusiastic to switch the brand and customers at the highest level showed their commitment to the brand. Oliver (1997) theorized that customers first become loyal in a cognitive sense (loyalty based on brand beliefs), then in an affective sense (a liking for the subject has developed), thirdly, in a cognitive sense (behavioural intentions have formed) and, lastly, loyalty is exhibited in the form of action, where the intent is turned into behaviour. The psychological and economic perspective of brand loyalty was studied by both Morgan and Hunt (1994) and Bandapudi and Berry (1997). Bendapudi and Berry (1997) found that customers remain attached to a brand because either they like it, or they may not have any other option to choose from. Johnson (1982) identified that economic, social and psychological limitations will create the constraint-based loyalty amongst the customers. On the other hand, some customers may desire to continue with their association with a brand based on their dedication. Such dedication may trigger loyalty supporting factors and constraints may increase the loyalty depressing factors. (Bendapudi and Berry 1997).

The loyalty of the customers is made up of both loyalty supporting factors and loyalty suppressing factors. While the loyalty supporting factors trigger, establish and sustain the positive relationship between the brand and customer, whereas, loyalty repressing factors create negativity in the minds of customers about the brand, planting the seeds of disharmony in the brand relationship. The following table summarizes the contribution of researchers on the topic loyalty supporting and loyalty repressing factors.

Table-01: Sources of loyalty supporting and repressing factors

\begin{tabular}{|l|l|l|l|}
\hline Source of Factors & Derived From & Definition & Retail Example \\
\hline Environment & $\begin{array}{l}\text { Halinen (1994), Bendapudi and } \\
\text { Berry (1997) Fournier (1998) } \\
\text { Roos (1999) }\end{array}$ & $\begin{array}{l}\text { Factors emerged outside the } \\
\text { influence of customer provider } \\
\text { dyad. }\end{array}$ & $\begin{array}{l}\text { Market Situation } \\
\text { Competitor's actions }\end{array}$ \\
\hline Service Provider & $\begin{array}{l}\text { Halinen (1994), Bendapudi and } \\
\text { Berry (1997) Fournier (1998) } \\
\text { Roos (1999) }\end{array}$ & $\begin{array}{l}\text { Factors trigged by provider or the } \\
\text { customer perception towards the } \\
\text { provider. }\end{array}$ & Image of the Retailer \\
\hline Customer & $\begin{array}{l}\text { Halinen (1994), Bendapudi and } \\
\text { Berry (1997) Fournier (1998) } \\
\text { Roos (1999) }\end{array}$ & $\begin{array}{l}\text { Factors triggered by the personality } \\
\text { or life situation of the customer. }\end{array}$ & $\begin{array}{l}\text { Changes in the customer life } \\
\text { situation } \\
\text { The expertise of the customer }\end{array}$ \\
\hline Interaction & $\begin{array}{l}\text { Halinen (1994), Bendapudi and } \\
\text { Berry (1997) Fournier (1998) } \\
\text { Roos (1999) }\end{array}$ & $\begin{array}{l}\text { Factors emerged out of interaction } \\
\text { between service provider and the } \\
\text { customer. }\end{array}$ & $\begin{array}{l}\text { Positive and negative incidents. } \\
\text { Satisfaction/dissatisfaction }\end{array}$ \\
\hline Product/Core Service & Halinen (1994) & $\begin{array}{l}\text { Factors triggered by the } \\
\text { characteristics of product or service. }\end{array}$ & $\begin{array}{l}\text { Prices, margins, interest rates, } \\
\text { availability of loans. }\end{array}$ \\
\hline
\end{tabular}

Source: Hardman. C. (2004)

Table-02: Loyalty Supporting Factors

\begin{tabular}{|c|c|c|}
\hline Author & Primary Factor & Secondary Factor \\
\hline Rose, et.al (2012) & $\begin{array}{ll} & \text { Ease-of-use } \\
\text { - } & \text { Personal Control } \\
\text { - } & \text { C2C interaction } \\
\end{array}$ & $\begin{array}{ll}\text { 1. } & \text { Navigation } \\
\text { 2. } & \text { Search } \\
\text { 3. } & \text { Structure } \\
\end{array}$ \\
\hline Lightner, et.al & - $\quad$ 1.Information Quality & 1. $\quad$ Price \\
\hline
\end{tabular}




\begin{tabular}{|c|c|c|}
\hline (2003) & - $\quad$ 2. Information Quantity & $\begin{array}{ll}\text { 2. } & \text { Navigation } \\
\text { 3. } & \text { Buying Speed }\end{array}$ \\
\hline Gentile, et.al. (2007) & $\begin{array}{l}\text { Balance between utilitarian } \\
\text { and hedonic value. } \\
\text { Balance between customer } \\
\text { expectation to stimuli from } \\
\text { the interaction with the } \\
\text { company. } \\
\text { - Own unique experience } \\
\text { - Continuum of experience. }\end{array}$ & \\
\hline Novak et.al (2000) & $\begin{array}{ll}- & \text { Customer support } \\
\text { - } & \text { Variety } \\
\text { - } & \text { Quality information }\end{array}$ & $\begin{array}{ll}\text { 1. } & \text { Ease of Order } \\
\text { 2. } & \text { Ease of Contact } \\
\text { 3. } & \text { Ease of Payment } \\
\text { 4. } & \text { Ease of Returns } \\
\text { 5. } & \text { Speedy Delivery }\end{array}$ \\
\hline $\begin{array}{l}\text { Smith \&Sivakumar } \\
\text { (2014) }\end{array}$ & $\begin{array}{ll}- & \text { Visual presentation of information. } \\
\text { - } & \text { 2. Clarity of Text }\end{array}$ & \\
\hline Trevinal et.al (2014) & $\begin{array}{ll}- & \text { User friendly navigation } \\
\text { - } & \text { Control } \\
\text { - } & \text { Visual aspects }\end{array}$ & \\
\hline
\end{tabular}

Source: Compiled by the Authors.

Table-03.: Customer loyalty suppressing factors

\begin{tabular}{|l|l|ll|}
\hline \multicolumn{1}{|c|}{ S1. No } & \multicolumn{2}{|c|}{ Authors } & \multicolumn{2}{c|}{ Loyalty Suppressing Factors } \\
\hline 1 & Rose et.al (2012) & 1. & Difficulties in the navigation. \\
& & 2. & Too much of information \\
\hline 2 & Novak, et.al (2000) & 1. & Lack of Reliability \\
& & 2. & Lack of Security \\
& & 3. & Higher Prices \\
\hline 3 & Gentile, et.al (2007) & 2. & Low Utilitarian Value \\
& & 1. & Information overload. \\
\hline 4 & Mostellor et.al (2014) & \\
\hline
\end{tabular}

Source: Compiled by the Authors

Therefore, from the review literature on consumer loyalty and disloyalty, it can be understood that the customer loyalty is dependent on both loyalty supporting and loyalty suppressing factors. Though, companies like to believe that there are no negative factors or absence of loyalty suppressing factors, but in contrary, there are many such loyalty repressing factors which can be detrimental in deciding the loyalty of customers towards the brands. In contrary, though omni channel marketing is a recent domain, but many of the scholars like Lim and Srai (2015), Mika Yrjola (2015), Wanda KledeSchnabel and Peter Bug (2016), Iguácel Melero, F. Javier Sese and Peter C. Verhoef (2016), Ana Grecu (2016), Rong Gao and Yi-Xiong Yang (2016), Lawrence Duane Casey (2017) and Chandra Hendriyani and Arianis Chan (2017) opine that Omni channel marketing connects all channels in a integrated manner to provide a superior customer experience and to gain a competitive edge over the rivals.

From the extensive review of the literature, it can be said that there are certain studies conducted independently on the topics of consumer loyalty, consumer disloyalty and Omni channel marketing, but there is a sheer lack of studies connecting both consumer disloyalty and Omni channel marketing. There are no studies carried out on using Omni channel marketing as a strategy to reduce the consumer disloyalty amongst the retailers. Hence, the present study intends to fill the gap in the existing literature and to provide valuable insights and suggestions for the marketers and retailers to use Omni channel strategy to contain and reduce the consumer disloyalty.

\section{The rise of connected and empowered consumer: issues and challenges}

The revolution of internet and resultant emergence of e-commerce has revolutionized the way how consumers engage with the brands. The way consumers browse shop and buy has fundamentally changed, necessitating the marketers to shun traditional strategies and structure and embrace the new age strategies. The exploration of digital technologies over the past decade has created a new set of "empowered" consumers so expert in their use of tools and information that they can order whatever they want, whenever they want and getting it delivered to their doorsteps at a rock-bottom price. Before the dawn of internet revolution, the flow of information was linear, unidirectional originating from 
companies/media houses to customers. But the diffusion of internet has not only brought drastic changes across the world, but in India too. Gone were the days, when consumer was at the mercy of company as for as his consumer experience is concerned, whereas, today, with the unleashing of digital world, this is no more common phenomenon to be seen or witnessed. (ShashankSinha, 2015).

The below drawn figure no.1 narrates the differences between traditional and new marketing funnel and its implications for the managers.

Figure-01: Traditional and New Marketing Funnel

Then: The purchase funnel

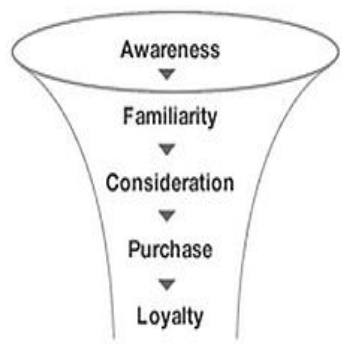

Now: The consumer decision journey

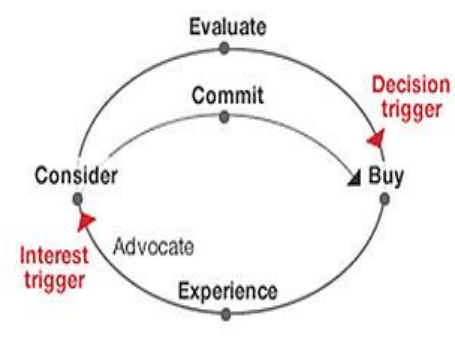

Source: McKinsey \& Company

Even in case of consumer decision journey, which was the alternative to the marketing funnel has also undergone drastic change in the digital age. In the classic journey, consumers engage in an extended consideration and evaluation phase before either entering the loyalty loop or proceeding into a new round of consideration and evaluation that may lead to the subsequent purchase of a different brand. The new journey compresses consider step and shortens or eliminates the evaluate step, delivering customers directly into the loyalty loop and locking them within it.

Figure -02: Classic and New Consumer Journey

Before

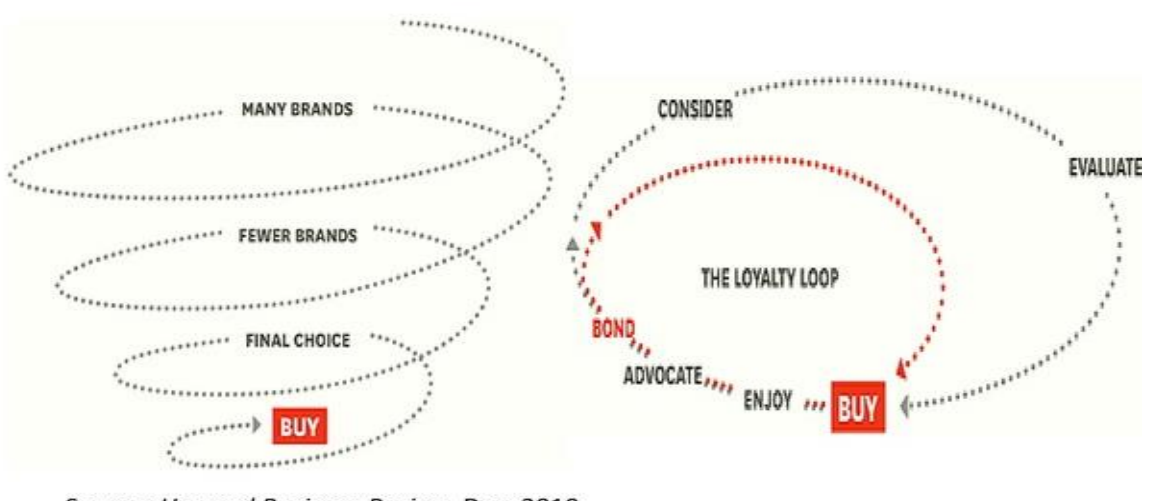

The boundaries between the online and offline shopping are blurring rapidly with the emergence of new kind of consumer i.e., the Omni-channel consumer. The new breed of Omni-channel consumer is faster, accurate, knowledgeable and sophisticated than the traditional consumer. The sudden emergence of this new kind of consumer has got lots of implications and repercussions for the traditional marketing strategies addressing both brand loyalty and brand disloyalty. (Gareth Jude, Christena Singh, Jenny Wilson, 2012).

There is a sublime difference in the way traditional and new age Omni-channel consumers behave in their consumer journey. For example, when the traditional consumer makes his decision by sourcing conventional sources of information like print media or television advertisement, whereas, the Omnichannel consumer makes use of internet to compare the value of one against other. Omni-channel 
consumer keeps his options open till the point of sale. The choice of the traditional consumer is limited to contents of a physical store, whereas his counterpart, searches, finds and orders them across the borders.

Figure-03: The Omni-Channel Purchase Journey
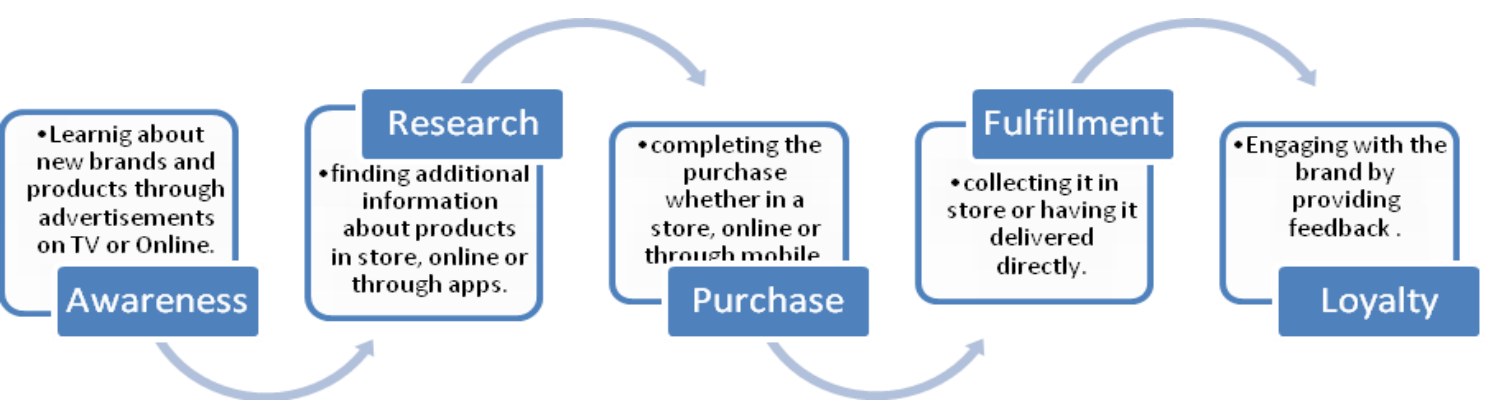

Source: The Economist: Planet Retail; Deloitte Consumer Survey, 2013.

Hence, it has been observed that making customers stay loyal to a brand is tougher in both real and digital world. A global survey by US- based Dyn in early 2015 revealed that almost 42 percent of online shoppers would wait only for few seconds before they shift to the rival brand. It becomes imperative for the retailers to catch up with the customer psyche throughout the consumer decision journey instilling a sense of belongingness and loyalty in every stage of their journey.

\section{How to win back the disgruntled consumer: the omni channel way}

The new age consumer is not constrained by the restrictions imposed by the seller, now he may search for the information from multiple channels and order from other channels at his own convenience and speed. Clearly, the bargaining power has shifted from seller to buyer with the multitude of options to choose and multiple channels to serve him. Therefore, consumers are really becoming mobile, shop anytime, anywhere and research items, regardless of the channel used. The purchase journey has become flexible and sophisticated as a result of the wider range of channels connected consumers while shopping. In such environment, a presence across channels helps retailers ensure that consumers can find them and engage with them at any stage of the shopping journey. This is what Omni channel marketing delivers to the marketers and retailers in keeping consumers engaged across all channels and delivering value to them through uninterrupted and seamless service.

The term "Omni-channel" has been around for quite some time, but the traction has increased only in the last few years. The origin of word omni comes from the word Omnis, meaning universal, whereas, the word multi-channel originated from the word Multus, meaning multiple or many and the word cross-channel emerged from the Latin word Crux meaning to go across. In essence, omni channel is improved and better version of multi-channel approach providing customer with a unique and seamless experience by enhancing his buying experience. The origin and evolution of Omni-channel is explained in the below drawn table.

Table-04: The Evolution of Omni-Channel over the years

\begin{tabular}{|c|c|c|c|}
\hline $\begin{array}{l}\text { Single Channel } \\
\text { (The Past) }\end{array}$ & $\begin{array}{l}\text { Multi Channel } \\
\text { (The First Step) }\end{array}$ & $\begin{array}{l}\text { Cross Channel (The } \\
\text { Current State) }\end{array}$ & $\begin{array}{l}\text { Omni-Channel } \\
\text { (The Future) }\end{array}$ \\
\hline \multirow{5}{*}{$\begin{array}{l}\text { Retailer most often } \\
\text { had only one } \\
\text { channel, example a } \\
\text { shop or only } \\
\text { catalogues (mail } \\
\text { orders). }\end{array}$} & Channels are standalone. & $\begin{array}{l}\text { Alignment in brand } \\
\text { experience, assortment, } \\
\text { prices etc. }\end{array}$ & $\begin{array}{l}\text { Consistent experience across } \\
\text { all channels. }\end{array}$ \\
\hline & $\begin{array}{l}\text { Customer comforted with } \\
\text { different assortment, prices, } \\
\text { deals etc. }\end{array}$ & $\begin{array}{l}\text { Back office (Organization, } \\
\text { systems) however not } \\
\text { integrated. }\end{array}$ & $\begin{array}{l}\text { Marketing not scattered, } \\
\text { systems integrated, customer } \\
\text { has seamless experience while } \\
\text { moving between channels. }\end{array}$ \\
\hline & $\begin{array}{l}\text { E-commerce is separate } \\
\text { system are silo-ed. }\end{array}$ & $\begin{array}{l}\text { Aligned brand messages } \\
\text { and channel offerings. }\end{array}$ & Brand experience \\
\hline & $\begin{array}{l}\text { Inconsistencies in brand } \\
\text { appearances }\end{array}$ & Extended online capabilities & $\begin{array}{l}\text { Different responsibility for } \\
\text { each channel. }\end{array}$ \\
\hline & $\begin{array}{l}\text { Online limited to must have } \\
\text { features, services. }\end{array}$ & $\begin{array}{l}\text { Comprehensive assortment } \\
\text { concepts. }\end{array}$ & $\begin{array}{l}\text { Assortment strategies aligned } \\
\text { with how customer shops }\end{array}$ \\
\hline
\end{tabular}




\begin{tabular}{|l|l|l|l|}
\hline & & & \\
\cline { 2 - 4 } & $\begin{array}{l}\text { Online assortment less } \\
\text { purposefully defined. } \\
\text { No specific price for online } \\
\text { market. }\end{array}$ & $\begin{array}{l}\text { Dynamic pricing. } \\
\text { Focused marketing to } \\
\text { specific segments. }\end{array}$ & Flexible order and fulfillment \\
\cline { 2 - 4 } & Unconnected marketing & & Individualized marketing. \\
\cline { 2 - 4 } & & & $\begin{array}{l}\text { Cross-channel organizational } \\
\text { structure and metrics. }\end{array}$ \\
\hline
\end{tabular}

Source: Compiled by the Author.

When compared to the other channels being used by the marketers, omni channel is the only channel which ensures the true continuity of seamless experience to the customers. It provides a single face or platform with seamless and personalized experience across all channels for the consumers for their continuous and consistent engagement to enrich their experiences with the brand. Omni-Channel marketing creates the value for customers as shown by the conceptual model drawn below.

Figure-04: Creation of Customer value through Omni channel

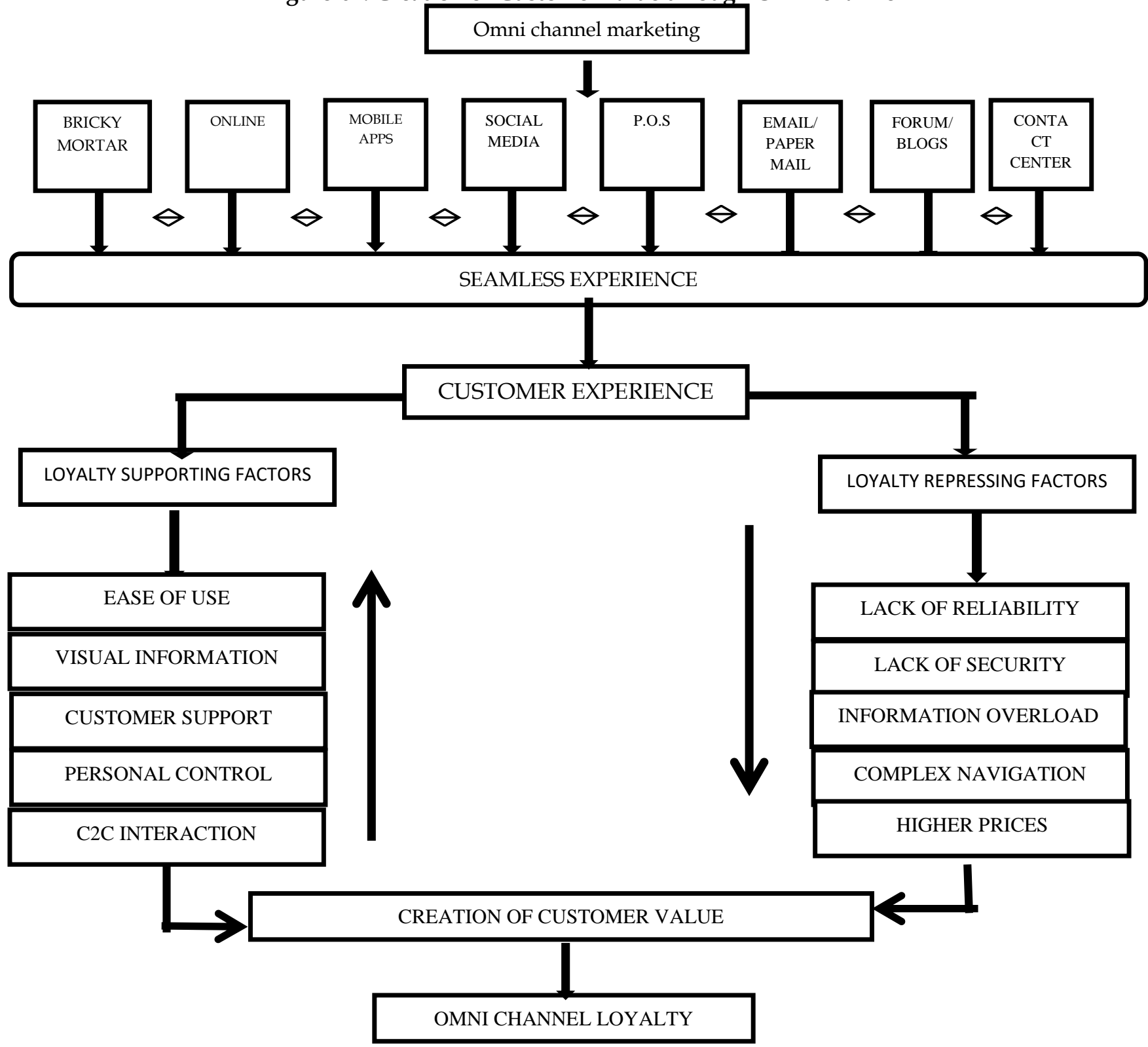

www.jbrmr.com A Journal of the Academy of Business and Retail Management (ABRM) 


\section{Conclusion}

In a dynamic market and situation, where the boundaries between digital and brick and mortar are rapidly blurring, brands, marketers and retailers have no other option but to accept the reality that they need to embrace the change in consumer purchase journey and the multiple channels they use in their various phases of their purchase journey. Brands and marketers need to anticipate the changes in consumer psyche and address the needs of the consumers, by unifying all the channels for delightful customer experience. The loyalty of the consumer cannot be just achieved by the advertising gimmicks or cosmetic changes in the interaction with them, but it can be built, sustained and treasured for the long run only by establishing an emotional and normative attachment between the brand and the consumer. Therefore, by adapting the Omni channel marketing brands, marketers can adapt to these rapid changes effectively and promptly serving empowered but disloyal consumers, they can still maintain and expand their position in the market.

\section{Limitations of the study}

The following are the limitations of the study.

1. This study is based on observation and review of literature.

2. This study is not based on primary data collected from the stakeholders on the field.

3. This study mainly focuses on how Omni channel strategy would increase the loyalty of the customer, but narrowly explains the value creation in the process.

\section{Scope for further research}

1. There is still scope for further research on this topic as there is no mature model of Omni-channel marketing developed for the brands, retailers and marketers.

2. The empirical evidence of the adaptation of Omni-channel and its success in creation of Omnichannel loyalty can be probed further.

\section{References}

Aaker, D.A. (1991): “Managing Brand Equity: Capitalising on the value of a Brand Name”, New York: Free Press.

Ana Grecu (2016) "Omni-Channel Retailing-Towards Factors which affect a Shopping Journey unpublished master thesis submitted to Aalborg University, Denmark.

Bendapudi, N and L.L. Berry (1997): Customer's Motivations for maintaining relationships with service providers, Journal of Retailing, Spring Vol.73, Issue 1. Pp 15-38.

Brown. G. H. (1952): Brand Loyalty-Fact or Fiction? Advertising Age, Vo.23. pp.53-55.

Chandra Hendriyani and Arianis Chan (2017) "Understanding the New Millennial Customer Path in the Era of OmniChannel Marketing in Indonesia" Review of Integrative Business and Economics Research, Vol. 7, Supplementary Issue 1.

Churchill. H. (1942): How to Measure Brand Loyalty, Advertising and Selling, 35.24.

Cunningham. R. M. (1956): Measurement of Brand Loyalty. In D. Cox (Ed) Risk taking and Information Handling in Consumer Behaviour. Boston. Harvard University Press. Pp.507-523.

Dick, A.S. and K. Basu (1994): Customer Loyalty: Toward and Integrated Conceptual Framework, Journal of the Academy of Marketing Science, Vol.22. No.2. pp 99-113.

Fournier, S. (1998): Consumers and their Brands: Developing Relationship Theory in Consumer Research, Journal of Consumer Research, Vol. 24, March, pp.343-368.

Frank. R.E. (1962) Brand Choice as Probability Process, Journal of Business, 35, pp.43-56.

Gentile, Spiller, Noci, (2007). "How to Sustain the Customer Experience: An overview of Experience Components that Co create Value with the Customer" European Management Journal Vol. 25, No. 5, pp. 395-410, 2007.

Halinen, A (1994) Exchange Relationships in Professional Services: A Study of relationship development in the Advertising Sector: Doctoral Dissertation, publication of Turku School of Economics and Business Administration, Turku.

Iguácel Melero, F. Javier Sese and Peter C. Verhoef (2016) UNIVERSIA BUSINESS REVIEW | SECOND QUARTER 2016 | ISSN: 1698-5117.

Jones, T.O., Jr.W. Earl Sasser (1995): Why Satisfied Customers Defect, Harvard Business Review, Nov/Dec, Vol. 73, Issue. 6. Pp. 88-102.

Johnson, M.P. (1982): Social and Cognitive Features of the Dissolution of commitment to relationships, in S. Duck (Ed): Personal Relationships: Dissolving Personal Relationships, New York, Academic Press, pp. 51-73.

Kuehn. A. A. (1958): An Analysis of the Dynamics of Consumer Behaviour and its implications of marketing Management, Unpublished Doctoral Dissertation. Pittsburgh: Carnegie Institute of Technology. 
Lawrence Duane Casey (2017) “Addressing gaps in supply chain technology for Global Omni Channel Retailers" Dissertation submitted to University of Oregon, Oregon.

Lipstein, B. (1959): The Dynamics of Brand Loyalty and Brand Switching, Proceedings, Fifth Annual Conference of the Advertising Research Foundation, New York.

Lightner, N., (2003) "What users want in e-commerce design: effects of age, education and income” Ergonomics, 2003, Vol.46, No.13, pp153-168.

Lim, S. F. W. T. and J. S. Srai. 2015. A network configuration perspective on e-commerce driven last-mile supply chains: Key configuration dimensions and mapping toolset. In: 20th Logistics Research Network Annual Conference. Derby, UK.

Michaud-Trévinal, A., and T. Stenger. (2014). "Toward a conceptualization of the online shopping experience". Journal of Retailing and Consumer Services 21 (3):314-326.

Mosteller, J., Donthu, N., Eroglu, S., (2014) “The Fluent Online Shopping Experience.” Journal of Business Research 67 (11), 2486-2493.

Mika Yrjölä (2015) “Departures to Executive Decision Making in Omni Channel Retailing” Dissertation submitted to Tampere University Press, Tampere.

Morgan, R. and S. Hunt (1994): The Commitment-Trust Theory of Relationship Marketing. Journal of Marketing 58, July 20-38.

Novak, T., Hoffman, D., Yung, Y., (2000) “Measuring the Customer Experience in Online Environments. A: Structural Modeling Approach" Marketing Science, Vol. 19, No. 1, Special Issue on Marketing Science and the Internet (winter, 2000), pp. 22-42.

Oliver, R. (1997): Satisfaction. A Behavioural Perspective on the Consensus: McGraw Hill.

Roos, I. (1999): Switching Paths in Customer Relationships, Doctoral Dissertation, No. 78, Publications of the Swedish School of Economics and Business Administration, Helsinki, Finland.

Rose, S., et al., 2012Online Customer Experience in e-Retailing: An empirical model of Antecedents and Outcomes. Journal of Retailing 88, 308-322.

Rong Gao and Yi-Xiong Yang (2016) “Consumer's Decision: Fashion Omni Channel Retailing” Journal of Information Hiding and Multimedia Signal Processing, Volume 7, Number 2, March 2016.

Smith, D. N., E Sivakumar, K. (2004). "Flow and internet shopping behavior: A Conceptual Model and Research Propositions". Journal of Business Research, 57(10), 1199-1208.

Wanda Klede-Schnabel and Peter Bug (2016) “Customer Loyalty Programs in Fashion Retail-A Change from Multichannel to Omni channel" Reutlingen University 2016, Reutlingen. 